\title{
15
}

\section{New Zealand's economic turnaround: How public policy innovation catalysed economic growth}

\author{
Michael Mintrom and Madeline Thomas
}

On 14 June 1984, New Zealand prime minister Sir Robert Muldoon announced a snap general election, to be held the following month. Muldoon, then in his 60s, had served continuously as both prime minister and finance minister since 1975. As prime minister, Muldoon wielded significant power in his Cabinet and in the conservative National Party. His election announcement was calculated to catch the Labour Party opposition off guard. But Muldoon's snap election announcement saw hubris triumph over astute political judgement. On 14 July 1984, David Lange, a charismatic politician in his early 40 s, a lawyer by profession with a quick and cutting wit, led the Labour Party to victory in an electoral landslide.

Following the 1984 general election, there was a broadly shared sense that the country faced new possibilities. Those new possibilities were seized, but in ways that many people did not expect. Significant public policy innovations were introduced. In the process, considerable economic and political disruption ensued. Disputes concerning economic management and social policy within the Labour Party saw the National Party win the 1990 general election. The newly elected National Government broadly 
accepted the inherited policy settings. Policy development continued across the spectrum of government activities under the direction of various Labour and National governments over the subsequent decades. Nonetheless, the key public policies adopted between 1984 and 1990 remain in place and have been the foundation for later policy development.

\section{A policy success?}

Starting in 1984, Lange and a very capable group of Cabinet colleagues introduced a comprehensive and intellectually coherent range of public policy innovations. They had major impacts on the functioning of both the New Zealand economy and the New Zealand public sector. Here we discuss four areas of innovation: 1) reduction of market interventions; 2) simplification of the tax system and the introduction of a goods and services tax (GST); 3) creation of state-owned enterprises (SOEs) and subsequent privatisation efforts; and 4) introduction of independence for the Reserve Bank in driving monetary policy. The success of public policies can be assessed from a number of perspectives. These policy innovations have now remained in place for decades. Thus, judged by endurance, they have been highly successful. We also consider their success from programmatic, process and political perspectives.

From a programmatic perspective, the changes in economic policy were intended to reduce government interventions in the economy and, in the process, improve the government's fiscal position. A highly coherent theory of change guided the development of these policy innovations. After a relatively short time, it was clear the changes were producing beneficial outcomes. However, there were adjustment costs, which were manifest most starkly in unemployment figures, which rose during the 1980s and took many years to decline.

From a process perspective, the policy innovations were well designed and generally well managed. Changes to market interventions and taxes were implemented swiftly. In the case of the introduction of the GST, implementation was delayed to ensure it would work effectively. Creation of SOEs took much more planning. The subsequent privatisation process did not always go smoothly. The change to monetary policy was carefully planned and implemented. Reform of market interventions and the sale of SOEs contributed to unemployment. Other than this, there were limited negative consequences of these policy innovations. 
From a political perspective, the story is more complicated. These policy innovations generated losses for certain sectors of the economy, and those who bore the brunt voiced their opposition. The government elected in 1984 was returned to power in 1987 after a strong electoral win. However, shortly afterwards, the governing coalition began to fragment. The epicentre of this fragmentation was the relationship between prime minister Lange and finance minister Roger Douglas. That relationship deteriorated as Douglas pushed to extend the logic of the limited state through extensive sales of government assets and changes in social policy. Lange pushed back, voicing his concern over the social costs of the reforms that had already been adopted.

The story we tell has been told before in different ways. Economists have tended to view the innovations positively. Using a set of key indicators, they have shown that the policy changes were both dramatic in how they halted specific past practices and significant in the positive impacts they delivered (Bollard 1994; Brash 1996; Evans et al. 1996). In contrast, various assessments have viewed these policy reforms negatively. In such interpretations, the changes have been considered unnecessarily radical, given the prevailing economic conditions when they began (Goldfinch and Malpass 2007). The policy innovations have also been construed as following too slavishly the predominant international fashion in economic thinking at that time (Larner 1997; Goldfinch 1998). Others have pointed to both the economic and the social costs of adjustment and have suggested the changes did more harm than good (Kelsey 1997; Dalziel 2002). Still others have noted how the policy innovations served to reduce the reach of the state and have suggested the end result was a significant redistribution of power into the hands of globalised financial elites (Easton 1997; Jesson 1999).

Our contribution involves analysing the economic turnaround as a public policy success. We take as our starting point the comprehensive assessments provided by well-placed economic observers of this period (Bollard 1994; Evans et al. 1996). We acknowledge the critiques. The reforms contributed to significant short-term stress in the New Zealand economy in the form of increased unemployment. This had highly damaging effects on vulnerable individuals, families and communities. In addition, aspects of the privatisation process were poorly handled. Where we depart from the critics is in our view of plausible alternative reform paths. No critical assessment has posited a set of counterfactual reforms that would have been achievable and more desirable than the path 
chosen. Paul Dalziel (2002) comes closest to offering such an assessmentbut that assessment discounts the seriousness of the imbalances in the New Zealand economy in mid-1984.

We next contextualise New Zealand's economic situation prior to 1984 and outline the four key policy innovations implemented between 1984 and 1990. In the decades since that period, these reforms have acquired strong political legitimacy. They have been accepted by successive governments embracing a range of different philosophical perspectives concerning good political and economic management.

\section{Context, challenges and agents}

Many commentators have described the New Zealand economy in 1984 as dysfunctional due to excessive government interventions. Lange quipped that, under the Muldoon Government: 'We ended up being run very similarly to a Polish shipyard' (Lange, quoted in New Zealand Herald 2005). That was an exaggeration (Goldfinch and Malpass 2007). Nonetheless, it has now been clearly documented that the economy at that time was subject to many unsustainable policies (Bollard 1994; Evans et al. 1996). They emerged from a specific historical period-from the end of World War II through to the mid-1970s. During that period, New Zealanders enjoyed high living standards relative to citizens of other countries (Easton 1997; Greasley and Oxley 2000). Policy approaches taken during those years of prosperity - which seemed beneficial to the country at the time- proved damaging when applied by Muldoon during his time as prime minister and finance minister. His approach to economic management fell out of step with the new orthodoxy in economic thinking that had been emerging internationally since the early 1960s. (Overviews of that new orthodoxy have been produced by, among others, Friedman 1962, 1977; Yergin and Stanislaw 2002; Greenspan 2008.)

It is useful to review the contextual factors and policy choices that created the economic and governmental management challenges the incoming fourth Labour Government faced in 1984. New Zealand became wealthy during the twentieth century through the export of meat, wool and dairy products (Hawke 1985). Most of those products were supplied to the United Kingdom. As early as the Great Depression, political leaders in New Zealand recognised the risks in this economic model. Whenever the economy of the United Kingdom weakened, the New Zealand economy 
weakened, too. In response, governments acted to safeguard the New Zealand economy. One such action involved promoting the development of a significant manufacturing sector. By placing high tariffs on imported items, the government provided protection to fledging industries. The strategy was quite successful. Nonetheless, high tariffs made many imported goods expensive to consumers. The grumbling this caused was delayed largely because the economy was doing well overall. Those people who desired imported goods over domestic substitutes were prosperous enough to pay the higher prices the tariffs created. The result was bearable so long as average incomes were relatively high.

New Zealand developed a comprehensive welfare state during the twentieth century, built on systems established earlier (Mintrom and Boston forthcoming; Oliver 1988). Compulsory public education was introduced in the late nineteenth century, followed by the creation of systems to support public health. Rudimentary measures to provide income support to the most needy also dated back to the nineteenth century. Following the Great Depression, these forms of social security were expanded to include an unemployment benefit. During the years of growing prosperity after World War II, elements of the welfare state were expanded. In the 1970s, two expensive additions were made. The first was the introduction of the Domestic Purposes Benefit to support sole parents who could not participate in the workforce. Introduced in 1973, this was primarily a benefit for unmarried mothers, and it resulted in far fewer adoptions of children born out of wedlock. The second addition was the creation of national superannuation in 1977, under Muldoon's National Government. This was a generous pension payable from general taxes to all people over a designated age of retirement; it was not means tested. As the welfare state expanded over several decades, the government bureaucracy needed to maintain it also grew incrementally. Consequently, many systems of service provision were built around approaches established long before the middle of the twentieth century. Inefficiencies were noted (Polaschek 1958); however, there was no political appetite for reform.

Beginning in the mid-1970s, New Zealand started to experience levels of unemployment that were unusual, given it had enjoyed decades of full employment. This unemployment was driven by several factors. With the United Kingdom joining the European Community in 1973, the long-guaranteed market for New Zealand's agricultural exports shrank. Reduced export earnings dampened demand for locally manufactured products. Unemployment rose among unskilled agricultural workers and unskilled factory workers. 
The international oil shocks of 1973-74 and 1978-79 further adversely affected the New Zealand economy. Being highly dependent on foreign oil supplies, New Zealand was susceptible to the sharp price increases instigated by the Organisation of Petroleum Exporting Countries oil cartel. In response, Muldoon's National Government took various actions, the most significant of which was the introduction of a major infrastructure building program. Announced in 1977 under the label 'Think Big', the program was intended to deliver two positive effects for New Zealand. First, it was expected to further insulate the New Zealand economy from international market changes. The logic was that if the country produced more domestic energy and switched to the use of energy sources it had in abundance — such as natural gas and hydroelectricitysusceptibility to the adverse effects of international shocks would decline. The second intended effect was to create more work, in the same way that infrastructural projects in the 1930s had made use of surplus labour and kept many households afloat during the Great Depression. However, the extra employment generated by these projects was modest, due to significant advances in construction technology over previous decades.

New Zealand Government revenues throughout the twentieth century were based primarily on company and income taxes. Over years of economic prosperity, incremental increases in marginal income tax rates were judged broadly acceptable. By the late 1970s, high-income earners were subject to a marginal tax rate of 66 cents in the dollar. As economic conditions worsened in the late 1970s and early 1980s, the Muldoon Government began imposing new, highly targeted forms of taxation as revenue-raising initiatives. These produced various economic distortions. The National Government used other regulatory actions to address growing inflation, including the imposition in 1982 of a general freeze on wages and prices. Efforts were also made to fix interest rates.

By 1984, the New Zealand economy was subject to extensive government intervention. There was a popular but expensive welfare state. The government ran many businesses associated with the delivery of infrastructure. In addition, the government was continuing to administer an elaborate system of tariffs on imported goods and various forms of financial subsidies to the manufacturing and agricultural sectors. Individuals and households were feeling the effects of high taxes and various regulations intended to moderate the effects of New Zealand's long-term decline in economic prosperity. Despite it all, the economy was performing poorly. Policy actions that might have worked during 
a time of economic prosperity were no longer having positive effects. Sentiment grew that the government was exercising too much control over economic activity.

In describing this background, it is useful to note two other matters. First, during the early 1980s, the attention of many New Zealanders and their politicians was absorbed not by issues of economic performance and management, but by two other public issues: New Zealand's sporting contacts with South Africa and the country's stance on nuclear warfare. A tour of New Zealand by the South African Springboks rugby team in 1981 had generated high levels of political unrest. Sporting contact with South Africa was viewed as lending support to that country's apartheid regime. By allowing that tour to continue, Muldoon had gained many detractors (Fougere 1989). While the National Party subsequently won the election of 1981, it returned to power with a slim majority in parliament. With respect to nuclear issues, many New Zealanders were concerned that defence alignments with the United States were forcing the country to support a repellent form of weaponry. The Labour Party made clear in the early 1980s that, should it win government, it would declare New Zealand nuclear-free (Clements 2015).

The second matter to note concerns the development of alternative conceptions of economic management. Significantly, economic management was not at all central to the political campaign rhetoric or the party leader debates that took place in the month leading up to election day in 1984. Lange (2005: 163), who was about to lead the Labour Party to electoral victory, has been clear on this: 'The fact of it is that Labour went into the election without an agreed economic policy.' He has elaborated:

Our [Labour Party] differences over economic policy were not played out in public in the way we had argued about the nuclear-free policy. Towards the end of 1983 [Roger] Douglas [who was the party's finance spokesperson and would become the Minister of Finance after the July 1984 election] produced an economic policy package ... It was by any test a radical document ... I remember being surprised but not in the least perturbed. I expected him to think outside the square. The package was a long way from becoming policy. It would go to caucus and policy council and it would be thrashed about at the party conference in the second half of 1984. (Lange 2005: 162-3) 
The anticipated debate never happened. The Douglas proposals received mixed responses in the party. A rival view was put forward that acknowledged the need for economic adjustment but assumed the government would continue to play a leading role in economic activity. Geoffrey Palmer, who was deputy leader of the Labour Party and who would become deputy prime minister after the 1984 election, wrote a short paper to reconcile different viewpoints. When the snap election was called, Palmer's paper became the party's default policy.

How the Labour Party struck upon its economic policy tells us something about the lack of agreement within the party and the parliamentary caucus from the outset. There are other details worth noting. Most importantly, the economic policy package presented by Douglas was informed by advice he had received from the Treasury. When Lange assumed leadership of the Labour Party in February 1983, he appointed Douglas as his shadow Minister of Finance. Lange 'expected him to prepare for the day when the Muldoon government would be gone' (Lange 2005: 154). As shadow Minister of Finance, Douglas had a direct line of communication with the Treasury and its senior staff from February 1983. At this time, the Treasury had established a group of analysts in a division called Economics II. This division was led by Roger Kerr and comprised between 10 and 15 economists. Many of them had postgraduate degrees in economics and broadly supported the Chicago School view that limited government and reliance on market processes were key to economic efficiency. Kerr established a culture within Economics II whereby efforts to address challenging policy questions would begin with careful reading of relevant analysis in current economics journals. Through a long-established process of 'rotation' of economic analysts every few years across divisions of Treasury, the culture of the organisation was such that analysts well beyond Economics II were informed by this approach. Kerr was key to creating a think tank atmosphere in Treasury and emphasising the importance of clear expression in the presentation of policy advice. (Kerr left the Treasury in 1986 to lead the New Zealand Business Roundtable, a think tank that would have considerable influence on economic policy for the next two decades.)

New Zealand's economic problems were connected to a highly interventionist form of economic management. The changing global economic context and the rise of free-market economic orthodoxy suggested such policy mechanisms were outdated. People in and around the New Zealand Government, including Douglas and Treasury officials, recognised this. 


\section{Policy design and choice}

When Lange and his fellow Cabinet members were sworn into office, all were aware that drastic change was needed in the role played by government in the New Zealand economy. In those days, the New Zealand dollar was fixed at a constant level against the US dollar, with that level determined by the government of the day. During the brief election campaign, talk arose that the New Zealand dollar was overvalued and that a Labour Party electoral victory would be followed by a significant devaluation. Speculators began to sell New Zealand dollars and buy foreign currency, with the intention of selling that foreign currency at a profit once devaluation had occurred. The selling off of the New Zealand dollar forced the government to draw down on its foreign capital reserves. Following the Labour Party victory, senior officials from the Reserve Bank and Treasury advised that currency trading should be curtailed until a devaluation had taken place. Muldoon reluctantly agreed to demands from the incoming government to immediately devalue the New Zealand dollar by 20 per cent. This action stemmed the losses from the government's foreign capital reserves, but the crisis made clear that the old ways of doing things were not sustainable. Douglas (1993: 17) who was about to assume the role of Minister of Finance in the new government-later grouped the fixed exchange rate and the run on the dollar with a range of other government interventions in the economy that 'brought us to our knees in 1984'.

The Labour Party, delivering on an election promise, held the Economic Summit Conference at Wellington's parliament buildings over three days in September 1984. It was attended by representatives from government departments, the trade union movement, the business community, the primary production sector and social, community and other groups. David Lange chaired the event. The summit produced a communiqué unanimously endorsed by all delegates, stating:

The conference agrees that sound economic management must have five basic policy objectives - sustainable economic growth, full employment, price stability, external balance and an equitable distribution of incomewhile fully respecting social and cultural values and avoiding undue environmental costs. (ESC Secretariat 1984: 302-3) 
At the same time, the participants exhibited distinct differences in what they cared most about (Dalziel 1986). This was an early indication of the dilemmas Lange would confront as prime minister.

A significant program of public policy innovation was about to occur. Here, we discuss: 1) market interventions; 2) taxation; 3) SOEs and privatisation; and 4) monetary policy. An unusual degree of intellectual effort went into policy design at this time. Throughout the period 1984-90, the New Zealand Treasury was the most influential source of policy advice to the government. All of these initiatives had their origin in deliberations between Douglas, as finance minister, and Treasury officials. Of the relationship between Douglas and the Treasury, Lange (2005: 192) observed: 'Theirs was a perfect marriage.' Treasury analysts showed a great desire to engage with relevant literature and to seek insight from colleagues in other departments and from external experts as they pursued their planning work. Further, many policy proposals were developed in ways that allowed for high levels of public consultation. Debate within Cabinet and associated Cabinet committees was vigorous. Evidence of the careful policy design work is most readily found in the Treasury's post-election briefing papers produced in 1984 and 1987.

The papers of 1984 were subsequently made public as Economic Management (The Treasury 1984) — a book that provided an intellectually coherent blueprint for how the incoming government could go about implementing economic reforms. Most importantly, the message of the briefing papers was that market mechanisms tended to be superior to administrative systems for efficiently allocating resources in society. The papers proposed that efforts be made to promote greater efficiency in many areas of government activity. It was suggested that this could be done by reform of taxation and by having government entities operate consistently with the practices of private sector firms.

The Treasury produced another highly influential set of briefing papers for the incoming government in 1987. Titled Government Management (The Treasury 1987), this document discussed the role and limits of government and desirable ways to restructure the public sector. In addition, it provided a thorough discussion of appropriate directions for reform of social policy and reiterated many points made in 1984's Economic Management concerning the appropriate management of the macroeconomy. Christopher Hood, in his classic 1991 article on the New Public Management (NPM), said of Government Management that 
it "comes closest to a coherent NPM "manifesto", given that much of the academic literature on the subject either lacks full-scale elaboration or enthusiastic commitment to NPM' (Hood 1991: 6).

\section{Market interventions}

While Lange was chairing the economic summit and engaging in various prime ministerial activities outside the economic domain, Douglas was working with the Treasury on the government's first budget, delivered in November 1984. This budget made provision for the phased reduction of tariff protections for import-substituting industries and removal of a range of tax concessions and subsidies for the farming sector. The wage and price freeze introduced in 1982 was to end. By announcing these policy changes, Douglas revealed a preference for having markets and prices direct the allocation of resources in the economy, rather than arbitrary systems of government intervention. Consistent with this theme, Douglas announced that a comprehensive review of the tax system would be undertaken in 1985, paving the way for widening the tax base. He said that greater efficiency would improve New Zealand's economic performance but would not necessarily ensure that the benefits would be shared fairly. Therefore, he announced that the government would carry out a longer-term review of social policies to protect vulnerable groups and guaranteed adequate access to resources. (Subsequently, the Royal Commission on Social Policy was established in 1986.) The Budget included a package to provide substantial immediate relief to low-income families with dependent children. It also increased most other benefits and allocated more funds to education and health care. The Budget introduced a surcharge on the additional income earned by superannuants, which was unpopular with the elderly. However, it confirmed that the government was willing to remove pockets of privilege.

\section{Taxation}

The fourth Labour Government recognised that the taxation system it had inherited encouraged misallocation of resources. Too much weight was placed on the direct taxation of personal incomes. Because the overall tax base was narrow, average and marginal income tax rates were high. There was a view that this regime was encouraging tax avoidance and evasion. The government's long-term objective was to simplify the tax system, broaden the tax base and flatten the tax scale. Significant tax design work ensued, drawing on expertise both within and outside government. 
In 1986, all wholesale sales taxes were abolished and replaced with a broad-based value-added tax (the GST) with a single rate of 10 per cent (raised in 1989 to 12.5 per cent). The GST included everything except financial services in the tax net. This was done recognising that only by taking this approach would economic distortions be avoided and the compliance costs involved in collecting the tax minimised. At the same time, cuts were made in the rate of income tax: an earlier five-rate scale was cut to three rates, with the highest 48 cents in the dollar-down from 66 cents. This scale was simplified further in 1988, with a two-rate scale of 24 per cent and 33 per cent. The company tax rate was reduced from 48 per cent to 33 per cent in recognition of the desirability of having the company tax rate equal to the top personal rate. The overall effect of these measures was to reduce the proportion of tax revenue derived from income taxes. Consequently, New Zealand's tax structure came to be viewed internationally as one of the least distortionary.

\section{State-owned enterprises and privatisation}

When the fourth Labour Government assumed office, the government owned and operated many services that could potentially operate in private hands or at least in a business-like fashion. These services included the Bank of New Zealand, Air New Zealand, an international shipping line and all electricity generation and distribution facilities. During its time in power, the fourth Labour Government established such activities as SOEs. In its 1984 briefing to the incoming government, Economic Management, the Treasury had given initial advice regarding the merits of placing some government activities on a more commercial footing. At this time, other governments around the world had begun to step back from the control and ownership of many previously state-owned and operated assets. For example, under Margaret Thatcher's leadership, the Conservative Government in the United Kingdom was implementing a major program of commercialisation and privatisation of government activities (Abromeit 1988; Jenkinson and Mayer 1988). Douglas (1993: 178) recalled:

My first attempt to obtain agreement on a comprehensive approach to State-owned enterprise reform was in May 1985. I wanted to transform them into competitive State-owned businesses by removing their monopoly status wherever possible, and transferring any of their noncommercial obligations to other government agencies. Managers could then become personally accountable for SOE performance. 
The view was that many government activities that could and should operate on a commercial basis and face competition were actually a drain on public resources. Further, those presiding over them lacked accountability for their decisions.

In December 1985, the government announced the principles it would apply to SOEs in the future, which were subsequently incorporated into legislation. The attorney-general and deputy prime minister Geoffrey Palmer developed an umbrella statute to streamline the reform process. This became the State-Owned Enterprises Act, adopted in December 1986, which came into effect in April 1987. At that time, nine government entities became SOEs. In December 1987, Douglas announced the government's intention to significantly reduce its debt position through a program of asset sales. During the next two years, major privatisations included the Bank of New Zealand, Petrocorp, New Zealand Steel, the New Zealand Shipping Corporation, State Insurance and Telecom.

The changing status of these operations certainly resulted in greater efficiency, which was manifest in both lower production costs and improvements in customer services. There were two downsides. First, the privatisation process did not run smoothly in several instances. Second, the promotion of more efficient operations in several large industries contributed in the short term to increased levels of unemployment. These two matters tended to obscure many of the benefits that resulted for New Zealand from the SOE and privatisation agenda (Brash 1996).

\section{Monetary policy}

Following the exchange rate crisis of July 1984, the fourth Labour Government was keen to develop policy approaches that would, as Douglas put it, 'Muldoon-proof' key aspects of monetary policy (quoted in Brash 1996: 14). Two actions were taken towards this goal, both of which removed much of the potential for any government to capriciously intervene in the workings of the broader monetary system.

In March 1985, Douglas announced the floating of the New Zealand dollar. This was a significant move and followed discussions between the Reserve Bank and the Prime Minister and Cabinet (Lange 2005: 207). If the New Zealand dollar had been floating in 1984, the exchange rate crisis of July 1984 would never have happened. Under the change, the Reserve Bank would no longer announce official buy and sell rates for 
the New Zealand dollar, but it was not required to withdraw completely from the market and would still be instructed to meet the government's requirements for foreign exchange. This was important for debt servicing. The bank could also monitor market trends and developments through minor market dealings and retained the option of entering the market during episodes of undue volatility to smooth exchange rate fluctuations (Reserve Bank of New Zealand 1986: 14).

In May 1989, the government introduced the Reserve Bank of New Zealand Bill into parliament, where it was passed unanimously. This legislation was world-leading with respect to the level of independence that it accorded to the Reserve Bank. In subsequent years, many governments developed legislative frameworks for their central banks that were closely informed by the New Zealand model (Bernanke and Mishkin 1997). The legislation was based on several key principles. It was acknowledged that monetary policy can affect the rate of inflation; however, monetary policy should not be manipulated to promote faster rates of growth or to sustain higher levels of inflation. The Reserve Bank Act explicitly stated that monetary policy must be used for the sole task of 'achieving and maintaining stability in the general level of prices'. In practice, written policy target agreements are signed between the Minister of Finance and the bank's governor. This target was generally kept in the range of 0 to 2 per cent per annum. The framework has proven very successful and, since its enactment, inflation in New Zealand has been kept under tight control-a major improvement over the situation in the period from the mid-1970s to the mid-1980s.

\section{Delivery, legitimacy and endurance}

The public policy innovations introduced by the fourth Labour Government have stood the test of time. While unemployment continued to rise during the government's term in office, inflation was slowly brought into check. Likewise, the government's debt situation slowly came under control, although little debt reduction happened before 1990. Here, we discuss the delivery, legitimacy and endurance of the innovations.

All the innovations endured-including the privatisation of government assets, which was the most controversial. With the exception of the privatisation program, they were accorded a high degree of legitimacy from the outset. It was well understood that market interventions had 
become burdensome and frequently ineffectual during the Muldoon years. While the removal of subsidies to the farming sector brought a share of pain, it was relieved by removal of many import protections. The move to a more independent Reserve Bank came after several years of a floating New Zealand dollar, which was also viewed as a key element of market liberalisation; it was therefore uncontroversial.

With respect to changes in the taxation system, the flattening of the income tax scale was generally viewed favourably. Some members of the Labour Party expressed concern that this was benefiting the wealthy and middle class over the lower classes, but this was a minority view. Likewise, there were inevitable complaints about the introduction of the GST. However, the comprehensive nature of the tax, and the efforts made to compensate the worst-affected consumers via incremental adjustments in welfare benefits, ensured the grumbling rapidly dissipated. The creation of SOEs also acquired rapid legitimacy. While it added to unemployment levels, the move to achieve greater efficiency in these organisations also resulted in improved service provision for citizen consumers.

The privatisation program was much more problematic because asset sales can be complicated; implementation challenges were greater in this element of the reforms than in any other discussed above. Considerable privatisation was initiated before 1990, and the National Government elected in 1990 continued the program. This suggests that, overall, privatisation was a policy success. But it created major debate within the Labour Government and the Labour Party. Further, while this initiative was under way, Douglas was strongly advocating in Cabinet for major changes to social policy. In this, he was spurred on by advice from the Treasury, as illustrated in Government Management (1987). Lange's serious misgivings regarding the merits of privatisation and radical proposals for changes to social policy created a rift between him and Douglas.

\section{Problems with privatisation}

During his budget speech in parliament in June 1987, Douglas announced a program of asset sales to reduce government debt. Earlier in the year, an experiment with partial privatisation had occurred, when the government allowed the Bank of New Zealand to raise capital through selling shares to the public. Reflecting concerns within the broader Labour Party, Lange was uneasy with this new development that Douglas was introducing. Following the Labour Government's reelection in August 1987, Lange 
made changes in his Cabinet that were designed to reduce Douglas's influence. While Douglas remained the Minister of Finance, those who had supported him as associate finance ministers were moved to other portfolios. One of those was Richard Prebble, who became the Minister for State-Owned Enterprises. Other elements of the Cabinet changes were designed to protect the social policy portfolios from major reform efforts.

As the SOEs minister, Prebble received his advice from the Treasury and he remained close in his engagements with Douglas. Given Douglas's prior announcement to privatise assets, it now fell to Prebble to preside over the process of getting various SOEs ready for sale.

Concerned by how asset sales might be perceived by the Labour Party and the broader public, in November 1988, Lange moved to establish a review of the privatisation process. His view was that ministers needed to be distanced from the process, to avoid perceptions of undue influence and corruption. When Prebble refused to consult the Labour Party over the sale of the Shipping Corporation, Lange removed him from his role as SOEs minister. In a subsequent television interview, Prebble said Lange was acting like a dictator. The inevitable happened: Lange sacked Prebble from the Cabinet. The privatisation process continued. Views on how it faired are mixed. Jarrod Kerr and colleagues (2007) provide a positive assessment, noting that the asset sales greatly increased the size and value of the New Zealand share market and those who bought shares in privatised companies tended to receive better returns than the market average. Others have been more critical. For example, Brian Gaynor (2000) has suggested the government could have received more revenue from its various partial and full asset sales had it managed the sales process more carefully. A common view is that several wealthy New Zealanders and their companies benefited greatly from the privatisation process at the expense of the government and taxpayers (Jesson 1999). Certainly, there was a degree of exuberance and naivety about early aspects of the process. A fair assessment would be that some sales were poorly managed. The government needed to rely on third parties to coordinate sales, and this did not always go well. But there was also a lot of learning during the implementation process, which stretched over more than a decade. 


\section{Things fall apart}

Although few significant changes were made to social policy during the period 1984-90, discussion of social policy became a site of significant contestation within the fourth Labour Government. Douglas and Treasury advisors went to great lengths to dominate social policy discussions. When Douglas launched the privatisation program in December 1987, he also announced plans to reduce the income tax to a flat rate and to introduce a Guaranteed Minimum Family Income. This announcement was viewed as cutting across more consultative efforts regarding the direction of social policy-most notably, the work of the Royal Commission on Social Policy. In January 1988, Lange curtailed the flat tax and Guaranteed Minimum Family Income changes. From then on, tensions between Lange and Douglas precipitated the demise of the fourth Labour Government.

A month after sacking Prebble from Cabinet in November 1988, Lange accepted Douglas's reluctant resignation. In August 1989, when his Labour caucus colleagues voted for Douglas to return to Cabinet, Lange resigned as prime minister. The reform agenda of the fourth Labour Government ended. Former deputy prime minister Geoffrey Palmer became prime minister, lasting in the role for little over a year. He was succeeded by Mike Moore in September 1990. The next month, Moore led the Labour Party into the general election, which the Labour Party lost in a landslide to the National Party. Once acrimony between Lange and Douglas boiled over into Cabinet, the fourth Labour Government lost confidence in itself and, inevitably, the confidence of the electorate.

The 1990 election was not a referendum on the appropriateness of the fourth Labour Government's public policy innovations. Rather, it was a referendum on which politicians could now most effectively lead the government into the future. Even though a new government came to power in 1990, it did nothing to overturn the policies Labour had introduced. Indeed, the new National Government took those policies as foundations and built on them.

\section{Analysis and conclusions}

In the early 1980s, global events and the New Zealand Government's responses to them drove the country towards economic collapse. Debt, inflation and unemployment grew. To address the crisis, the fourth Labour Government introduced public policy innovations in the style of what 
came to be called New Public Management. The innovations set New Zealand on a path towards much improved economic conditions. Since then, governments displaying a variety of ideological commitments have had opportunities to abandon the innovations. While there has certainly been evolution and adjustment, the policies introduced in those years remain in place. That said, as a small trading nation, New Zealand will always be vulnerable to changing global market conditions. The policy innovations clarified what actions might be taken to maintain broadly positive economic conditions in the face of continuous challenges.

Given the unique nature of New Zealand democracy, its location and its economic foundations, care must be taken in drawing lessons for other countries from this policy success. In closing, we suggest several lessons for policy designers. Periods can arise when those in power are unwilling to make policy changes, even when evidence suggests change is necessary. When this happened in New Zealand in the early 1980s, key advisors kept working at developing their arguments for why change was needed and what changes would be most appropriate. They prepared for a change of government. The relationship between the Treasury and Roger Douglas was fundamental.

The case also seems to support the view that policy innovation occurs when political actors take advantage of windows of opportunity (Kingdon 1995). In 1984, it was clear the old ways of managing the economy were no longer working. There was no hope that economic circumstances would improve by doing more of what had been done in the past. What makes this case particularly interesting is that, when we stand back from the cut and thrust of politics of the period, we see a major battle of ideas was in play. New ideas about how to govern an economy were rapidly implemented. The short-term benefits that came from the policy innovations were sufficient to sustain their political legitimacy. That legitimacy ensured the innovations remained in place and could subsequently deliver longer-term benefits.

This case also underscores that sound policy innovation takes time. Time is required to determine appropriate directions forward and to consult about design issues. Through listening and working with others-even those who might have strong objections to a proposal—it is possible for advocates of change to improve policy design and build a strong coalition to support change. The converse is also true: trying to win debates without listening closely to others can derail change efforts and generate mistrust. 
Lost trust can be difficult to regain. The policy innovations discussed here certainly exhibited intellectual coherence; however, intellectual coherence is not a substitute for building and maintaining a powerful supportive coalition.

Given the pressures that central figures in the fourth Labour Government confronted, and others they created by pursuing a fast-paced reform program, perhaps it was inevitable that various forms of interpersonal acrimony would develop. Further, given that the Labour Party had many members who continued to believe in the power of government to do good things in society, in retrospect, it is hardly surprising that big clashes occurred in Cabinet. It is fruitful to reflect on this. What approaches to policy discussion, the implementation of the privatisation program and overall political management might have allowed this government to serve for longer? Looking back, Douglas took the view that moving rapidly on multiple policy fronts was the only way to secure fundamental changes. However, subsequent New Zealand governments have achieved important reforms while moving more slowly and working to ensure implementation is well managed. For example, the National Party-led coalition of 2009-17 established a new program of privatisation of government assets. Important work was done that drew on lessons from the past and that met considerable success. This suggests moving rapidly is not the only game in town; careful implementation planning is just as important as careful policy design.

The policy innovations introduced from 1984 to 1990 also demonstrate that achieving success in one area of policy innovation can sometimes lay strong foundations for achieving success in others. The reformers in New Zealand learned a lot about how the operations of the core public service could be improved through placing state trading activities on a commercial footing. They desired to transfer those lessons to social policy design. However, that pursuit of intellectual coherence was undercut by a lack of sophistication in the assessment of the political feasibility of such an agenda.

In sum, we judge New Zealand's economic turnaround to have been a major public policy success. Innovative public policy changes catalysed economic growth. In the process, much was learned about the role of government in the economy, how government might be effectively managed and how advisory systems might be structured to attend both to present challenges and to stewardship for the future. While problems 
certainly arose, the principles of policy design pursued during this reform period continue to be of relevance in many areas of public policy, well beyond those we have discussed.

\section{References}

Abromeit, H. 1988. 'British privatisation policy.' Parliamentary Affairs 41(1): 68-85.

Bernanke, B. S. and Mishkin, F. S. 1997. 'Inflation targeting: A new framework for monetary policy?' Journal of Economic Perspectives 11(2): 97-116. doi.org/ 10.1257/jep.11.2.97.

Bollard, A. 1994. 'New Zealand.' In J. Williamson (ed.), The Political Economy of Policy Reform. Washington, DC: Institute for International Economics.

Brash, D. 1996. New Zealand's remarkable reforms. Address to the Fifth Annual Hayek Memorial Lecture, London, 4 June. Available from: www.rbnz.govt. nz/research-and-publications/speeches/1996/speech1996-06-04.

Clements, K. 2015. Back from the Brink: The creation of a nuclear-free New Zealand. Wellington: Bridget Williams Books.

Dalziel, P. 2002. 'New Zealand's economic reforms: An assessment.' Review of Political Economy 14(1): 31-46. doi.org/10.1080/09538250120102750.

Dalziel, P. C. 1986. 'The 1984 economic summit conference: A search for policy objectives.' New Zealand Economic Papers 20(1): 41-51.

Douglas, R. 1993. Unfinished Business. Auckland: Random House.

Easton, B. H. 1997. The Commercialisation of New Zealand. Auckland: Auckland University Press.

Economic Summit Conference (ESC) Secretariat 1984. Economic Summit Conference: Proceedings and conference papers. Wellington: Government Printer.

Evans, L., Grimes, A., Wilkinson, B. and Teece, D. 1996. 'Economic reform in New Zealand 1984-95: The pursuit of efficiency.' Journal of Economic Literature 34(4): 1856-902.

Fougere, G. 1989. 'Sport, culture and identity: The case of rugby football.' In D. Novitz and B. Wilmott (eds), Culture and Identity in New Zealand. Wellington: P. D. Hasselberg, Government Printer. 
Friedman, M. 1962. Capitalism and Freedom. Chicago: University of Chicago Press.

Friedman, M. 1977. 'Nobel lecture: Inflation and unemployment.' Journal of Political Economy 85(3): 451-72. doi.org/10.1086/260579.

Gaynor, B. 2000. 'How asset sales went wrong.' New Zealand Herald, 30 June.

Goldfinch, S. 1998. 'Remaking New Zealand's economic policy: Institutional elites as radical innovators 1984-1993.' Governance 11(2): 177-207. doi.org/ 10.1111/0952-1895.00065.

Goldfinch, S. and Malpass, D. 2007. 'The Polish shipyard: Myth, economic history and economic policy reform in New Zealand.' Australian Journal of Politics \& History 53(1): 118-37. doi.org/10.1111/j.1467-8497.2007.00446.x.

Greasley, D. and Oxley, L. 2000. 'Outside the club: New Zealand's economic growth, 1870-1993.' International Review of Applied Economics 14(2): 173-92. doi.org/10.1080/02692170050024732.

Greenspan, A. 2008. The Age of Turbulence: Adventures in a new world. New York: Penguin.

Hawke, G. R. 1985. The Making of New Zealand: An economic history. Cambridge: Cambridge University Press.

Hood, C. 1991. 'A public management for all seasons?' Public Administration 69(1): 3-19.

Jenkinson, T. and Mayer, C. 1988. 'The privatisation process in France and the UK.' European Economic Review 32(2-3): 482-90. doi.org/10.1016/00142921(88)90194-8.

Jesson, B. 1999. Only Their Purpose is Mad: The money men take over New Zealand. Palmerston North, NZ: The Dunmore Press.

Kelsey, J. 1997. The New Zealand Experiment: A world model for structural adjustment? Wellington: Bridget Williams Books.

Kerr, J., Qiu, M. and Rose, L. C. 2007. 'Privatisation in New Zealand and Australia: An empirical analysis.' Managerial Finance 34(1): 41-52. doi.org/ 10.1108/03074350810838217.

Kingdon, J. W. 1995. Agendas, Alternatives and Publics Policies. 2nd edn. New York: Harper Collins.

Lange, D. 2005. My Life. Auckland: Viking/Penguin. 
Larner, W. 1997. “'A means to an end”: Neoliberalism and state processes in New Zealand.' Studies in Political Economy 52(1): 7-38. doi.org/10.1080/191870 33.1997.11675320.

Mintrom, M. and Boston, J. forthcoming. 'From social protection to social investment in Australia and New Zealand.' In K. Baehler and J. Straussman (eds), The Oxford International Handbook of Public Administration for Social Policy: Promising practices and emerging challenges. Oxford: Oxford University Press.

New Zealand Government 1984. View from the Summit: A look at the '84 economic summit conference. Wellington: Government Printer.

New Zealand Herald 2005. 'David Lange, in his own words.' New Zealand Herald, 15 August.

Oliver, W. H. 1988. 'Social policy in New Zealand: An historical overview.' In New Zealand. Royal Commission on Social Policy (ed.), The April Report. Volume 1. Wellington: Government Printer.

Polaschek, R. J. 1958. Government Administration in New Zealand. Wellington: New Zealand Institute of Public Administration.

Reserve Bank of New Zealand (various years). 'New Zealand economic chronology.' In Reserve Bank Bulletin. Wellington: Reserve Bank of New Zealand.

The Treasury 1984. Economic Management. Wellington: Government Printer.

The Treasury 1987. Government Management. Wellington: Government Printer.

Yergin, D. and Stanislaw, J. 2002. The Commanding Heights: The battle for the world economy. New York: Basic Books. 
This text is taken from Successful Public Policy: Lessons from Australia and New Zealand, edited by Joannah Luetjens, Michael Mintrom and Paul 't Hart, published 2019 by ANU Press, The Australian National University, Canberra, Australia.

doi.org/10.22459/SPP.2019.15 